\title{
Male-Specific Volatiles Released by the Brazilian Papaya Weevil, Pseudopiazurus obesus: Partial Identification and Evidence of an Aggregation Pheromone
}

\author{
Paulo H. G. Zarbin, ${ }^{*, a}$ Marcos A. B. Moreira, ${ }^{a}$ Jenny Haftmann, ${ }^{b}$ Wittko Francke ${ }^{b}$ and \\ Alfredo R. M. Oliveira ${ }^{a}$ \\ ${ }^{a}$ Departamento de Química, Universidade Federal do Paraná, CP 19081, 81531-990 Curitiba-PR, Brazil \\ ${ }^{b}$ Institute for Organic Chemistry, University of Hamburg, Martin-Luther-King-Platz 6, D-20146, Hamburg, Germany
}

\begin{abstract}
A resposta comportamental de machos e fêmeas adultos de Pseudopiazurus obesus (Boheman, 1838) (Coleoptera: Curculionidae) a várias fontes de odores foi avaliada em um olfatômetro de tubo em Y. insetos machos e fêmeas foram significativamente mais atraídos para uma combinação dos voláteis emitidos pelos machos da espécie e pela planta hospedeira, sugerindo a existência de um feromônio de agregação produzido pelos machos. Análises comparativas dos voláteis emitidos pelos machos e fêmeas revelaram três compostos machoespecíficos, em uma relação de 77:14:9, dando suporte químico às observações comportamentais. $(1 R, 2 S)$-(+)-Grandisal e $(1 R, 2 S)$-(+)-grandisol foram identificados como sendo os compostos majoritário e intermediário, respectivamente, enquanto que a estrutura química do componente minoritário, que parece ser um novo derivado do grandisol, ainda necessita ser determinada. Estes três compostos são os principais candidatos a feromônio na espécie.
\end{abstract}

The behavioral responses of adult male and female Pseudopiazurus obesus (Boheman, 1838) (Coleoptera: Curculionidae) to several odour sources were evaluated in a Y-tube olfactometer. Males and females insects were significantly more attracted to a combination of volatiles released by males of the species and host plant, suggesting the existence of a male-produced aggregation pheromone. Comparative analysis of the volatiles released by males and females revealed three male-specific compounds, in a ratio of $77: 14: 9$, providing a chemical support to the behavioral observations. $(1 R, 2 S)-(+)-G r a n d i s a l$ and $(1 R, 2 S)-(+)$-grandisol were identified as the major and intermediate compounds, respectively, while the chemical structure of the minor compound, that seems to be a new grandisol derivative, still remains to be determined. These three compounds are the most important pheromone candidates in the species.

Keywords: Curculionidae, olfactometer, kairomone, grandisal, grandisol

\section{Introduction}

Larvae of the papaya borer weevil, Pseudopiazurus obesus (Boheman, 1838) (Coleoptera: Curculionidae), cause irreversible damage on papaya stalks due to the destruction of meristematic tissues and sap flow clogging and may kill a plant under high infestations. This species is only exposed to control measurements in its adult form, since larvae and pupae complete their development within the stalk; therefore, they are protected from conventional control methods based on chemical insecticides. ${ }^{1}$ The species is detected in all Northeast of Brazil, with special incidence in the States of Bahia and Rio Grande do Norte. ${ }^{1}$

*e-mail: pzarbin@quimica.ufpr.br
The combination of biological, behavioral, and chemical studies for the use of semiochemicals, particularly pheromones, has been applied and used in large scale against many agricultural pests, representing a safe and lasting alternative in control programs against insect pests by means of monitoring or mass trapping or disruption techniques, either to detect pest species or to prohibit the entry of nonnative species in the cultivated area. ${ }^{2}$

This study aimed at providing evidence for semiochemical mediation on the chemical communication between conspecific individuals in P. obesus, and to identify the candidate structures of corresponding compounds as a foundation for the further development of an integrated pest management program against the papaya borer weevil. 


\section{Experimental}

\section{Rearing of papaya borer weevils under laboratory conditions}

The insect colony was started by collecting pupae during 2002 and 2003 in papaya producing areas located near the cities of São José do Mipibu, Vera Cruz, and Monte Alegre, in the State of Rio Grande do Norte, Brazil. To obtain adult insects, pupae were placed in screened cages measuring $6 \mathrm{~cm}$ height by $15 \mathrm{~cm}$ diameter and taken to the Laboratory of Semiochemicals of the Department of Chemistry at Universidade Federal do Paraná (UFPR), in Curitiba, PR, Brazil. Pupae were kept for 25 days in an incubator, adjusted at 12 hours photophase: 12 hours scotophase, temperature of $26 \pm 2{ }^{\circ} \mathrm{C}$, and relative humidity of $75 \pm 10 \%$. Upon emergence, adult insects were sexed, ${ }^{3}$ and placed in plastic screened cages with ventilation at the sides and maintained under the same conditions as described above. Adults were fed a natural diet consisting of pieces of fresh papaya stalk. The cages were cleaned, and the food supply was replaced at regular intervals of three days.

\section{Collection of volatiles from male and female insects}

Groups of 30 males and females from 20-40 days old were placed in different all-glass aeration chambers, under the above mentioned climatic conditions, and the volatiles were trapped on Super Q (Alltech, Deerfield, Illinois, USA) columns for 24 hours. ${ }^{4}$ A humidified charcoalfiltered airstream $\left(1 \mathrm{~L} \mathrm{~min}^{-1}\right)$ was maintained through the aeration apparatus. The columns were washed with distilled hexane, and the extracts were concentrated to 1 insect equivalent $\left(1 \mathrm{IE} \mu \mathrm{L}^{-1}\right)$ under an argon stream in a clean conical bottom vial. ${ }^{5}$ Due to the fact that $P$. obesus needs the presence of food to release sex-specific components, ${ }^{6}$ the foodstuff was available for the insects on the aeration chamber during the all 24 hours of aeration (extract A) or; the foodstuff was removed from the aeration chamber after the first hour of aeration (extract B). This procedure was employed to guarantee the presence of sexspecific components in the extract and to avoid contaminations with plant volatiles.

\section{Laboratory bioassays}

Prior to the bioassays under olfactometer conditions, odor propagation simulation tests were performed to visualize the plume distribution inside the system. To accomplish this, hydrochloric acid and ammonium hydroxide were mixed, following the method described by Baker and Linn. ${ }^{7}$ The air speed in the system was adjusted to $2.5 \mathrm{~L} \mathrm{~min}^{-1}$, and it was previously humidified and filtered on active charcoal. The olfactometer consisted of a Y-shaped glass tube of $2.5 \mathrm{~cm}$ diameter. The aim tube of the olfactometer was $40 \mathrm{~cm}$ in length and the two arms were each $20 \mathrm{~cm}$ in length. Behavior of male and female papaya borers was bioassayed using the following test samples: 1) aerated extract of males (extract B) vs control (hexane solvent); 2) aerated extract of females (extract B) $v s$ control; 3) aerated extract of males (extract A) + food (fresh pieces of papaya stalk) $v s$ control; 4) aerated extract of females (extract A) + food vs control; 5) food $v s$ control (air); and 6) aerated extract of males (extract A) + food $v s$ food + hexane. Food stalk was added to guarantee the presence of very volatiles food components that, eventually, were not effectively trapped on Super Q. At the base of the olfactometer, 1 male or 1 female of $P$. obesus were placed. Tests, each lasting 15 minutes, were repeated 10 times. Above-mentioned samples were placed at the end of one of the arms, using filter paper impregnated with $3.0 \mu \mathrm{L}$ of the solution, while the same volume of hexane was used as a control at the end of the other arm. After the runs, the system was left running with clean air for additional 15 minutes, and the sources of odor were changed at the olfactometer arms to prevent the insects from getting habituated to possible odors trapped at those places. Bioassays were conducted 4 hours after the beginning of the scotophase, because this time corresponded to the period when male insects showed highest activity in the production of sex-specific volatiles. ${ }^{6}$ Only insects that reached the arms of the olfactometer and remained near the odor source were considered.

\section{Analytical procedures}

For gas chromatographic analyses (GC) and coupled gas chromatography-mass spectrometry (GC-MS), $1 \mathrm{~mL}$ of the extracts were injected into a gas chromatograph (model Varian 3800), equipped with FID, electronic pressure control, and operated in splitless mode. A VA-5 $(30 \mathrm{~m} \times 0.25 \mathrm{~mm} \times 0.25 \mu \mathrm{m})$ capillary column was used under temperature program: $50{ }^{\circ} \mathrm{C}$ for 3 min with an increase of $7{ }^{\circ} \mathrm{C} \mathrm{min}{ }^{-1}$ until $250{ }^{\circ} \mathrm{C}$ and maintained for additional $10 \mathrm{~min}$. Chromatograms obtained with extracts of females and males were checked for sex specific differences. Mass spectra were recorded on a Varian Saturn 2000 GC-MS-MS ion trap detector using the same type VA-5 capillary column under the same conditions as described above. Enantioselective gas chromatography was carried out by using a $25 \mathrm{~m} \times 0.25 \mathrm{~mm} \times 0.25 \mu \mathrm{m}$ 
fused silica capillary column coated with Hydrodex- $\beta-6$ TBDM (Macherey \& Nagel, Düren, Germany) under temperature program: $3 \mathrm{~min}$ at $60{ }^{\circ} \mathrm{C}$ then programmed to $180{ }^{\circ} \mathrm{C}$ at a rate of $3{ }^{\circ} \mathrm{C} \mathrm{min}{ }^{-1}$.

\section{Reference compounds, synthesis, and derivatizations}

Racemic grandisol (98\% purity) was purchased from Bedoukian Research Inc. (Danbury, CT, US). Pure $(1 R, 2 S)-(+)$-grandisol was kindly provided by Prof. Dr. Kenji Mori, Tokyo. ${ }^{8}$ The synthesis of grandisal from grandisol was carried out by oxidation with pyridinium chlorochromate. ${ }^{9}$ Micro-reduction of natural grandisal to grandisol was carried out by $\mathrm{LiAlH}_{4} \cdot{ }^{11}$ Preparation of the trifluoroacetate of grandisol was carried out according to Hibbard and Webster. ${ }^{10}$

\section{( \pm )-cis-1-Isopropenyl-1-methylcyclobutaneethanal (grandisal)}

Pyridinium chlorochromate adsorbed in $\mathrm{Al}_{2} \mathrm{O} 3$ (2.99 g; $2.43 \mathrm{mmol})$ was suspended in dry $\mathrm{CH}_{2} \mathrm{Cl}_{2}(18 \mathrm{~mL})$ at $25^{\circ} \mathrm{C}$. ( \pm )-Grandisol (0.15 g; $\left.0.99 \mathrm{mmol}\right)$ in $\mathrm{CH}_{2} \mathrm{Cl}_{2}(0.5$ $\mathrm{mL}$ ) was added in one lot to the stirred solution. After $2 \mathrm{~h}$, the black reaction mixture was filtered through a short pad of $\mathrm{SiO}_{2}, \mathrm{Celite}^{\circledR}$ and active charcoal. The solvent was removed under reduced pressure and the residue obtained $(0.12 \mathrm{~g})$ was directly analysed by GC-MS. The retention time and MS data of synthetic grandisal were identical to that of the major component of the natural pheromone.

\section{Micro-reduction of natural grandisal to grandisol}

The natural extract of P.obesus $(\sim 50 \mu \mathrm{L})$ was concentrated to $1-3 \mu \mathrm{L}$ and dissolved in dry $\mathrm{Et}_{2} \mathrm{O}$ (100 $\mu \mathrm{L}) . \mathrm{LiAlH}_{4}(1-4 \mathrm{mg})$ was added and the mixture was stirred at room temperature for $20 \mathrm{~min}$. Water $(100 \mathrm{~mL})$ was added and the organic layer was removed and dried over $\mathrm{Na}_{2} \mathrm{SO}_{4}$. The sample was directly analyzed by GCMS.

\section{Preparation of the trifluoroacetate of grandisol}

Grandisol (0.01 g; $0.06 \mathrm{mmol}$ ) was dissolved in $\mathrm{CH}_{2} \mathrm{Cl}_{2}$ $(2 \mathrm{~mL}$ ) and one drop of trifluoracetic anhydride was added. The solution was kept at $70{ }^{\circ} \mathrm{C}$ for $1 \mathrm{~h}$. The reaction mixture was evaporated to a few $\mu \mathrm{L}$ by a slow stream of argon, to remove the volatile trifluoroacetic acid formed. The residue was dissolved in hexane $(2 \mathrm{~mL})$ and analyzed directly by GC-MS. The natural extract of $P$. obesus was trifluoracetylated in a similar way. MS $(70 \mathrm{eV}): \mathrm{m} / \mathrm{z}(\%)$ : 250 (M+, 0.09); 235 (0.15); 222 (0.18); 136 (1.19); 121 (1.48); 109 (8.63); 93 (7.03); 69 (13.51); 68 (100); 67 (33.92); 53 (11.12); 41 (11.78).

\section{Statistical procedures}

The data obtained with insects that reached the corresponding odor sources were transformed to percentage values and means were compared by the $t$ test using the Statistic software package Stat Soft, Inc. ${ }^{12}$ Results showing $\mathrm{P} \leq 0.05$ were considered statistically significant.

\section{Results and Discussion}

Behavioral responses of $P$. obesus males and females to distinct treatments are shown in Table 1. In bioassay 1, the attractiveness of both sexes to the extract from male insects was not significantly different when compared with the control treatment $(\mathrm{P}>0.54)$, i.e., when evaluated alone, extracts from male insects did not significantly influence the behavior of their conspecifics. In bioassay 2, when compared with the control treatment, neither males nor females of $P$. obesus showed significant differences in the reaction to the extract from female insects $(P>0.21$ male and $\mathrm{P}>0.35$ female). Similar to the previous assay, the females proved to be not attractive to conspecifics.

In bioassay 3 , the evaluation of male and female insects to the extract of males added to fresh pieces of the host plant showed significant differences in attractiveness to both sexes when compared with the control treatment, with an attractiveness similar for males and females $(\mathrm{P} \leq$ 0.001). Bioassay 4 showed that the extract of female insects, added to fresh pieces of the host plant, did not significantly enhance the attractivity as compared to the control treatment $(\mathrm{P}>0.20$ for males and $\mathrm{P}>0.67$ for females). The results obtained in bioassays 2 and 4 demonstrated that the volatiles released from female insects, alone or in combination with the host plant, did not show any biological activity on conspecifics, indicating respective compounds not to be involved in aggregation and/or sexual behavior. On the other hand, the results of bioassay 3 suggest the existence of specific chemical compounds in male extracts, which perhaps could be responsible for chemical communication in the species.

In order to verify the activity of components present in the natural diet, the reaction of male and female insects to host plant volatiles vs control was evaluated in bioassay 5. As a result, both sexes were significantly attracted to plant volatiles but did not react to the control (air); ( $\mathrm{P}<$ $0.03)$ for males and $(\mathrm{P}<0.02)$ for females. However, plant volatiles proved to be less attractive to males and females than a mixture of volatiles of males and of their host components, as showed in bioassay 6; $(\mathrm{P}<0.004)$ for male and $(\mathrm{P}<0.006)$ for females. 
Table 1. Male and female $P$. obesus responses to distinct treatments in type Y-tube olfactometer

\begin{tabular}{|c|c|c|c|c|c|}
\hline \multirow{3}{*}{$\begin{array}{l}\text { Bioassay }^{a} \\
1\end{array}$} & \multirow{3}{*}{$\begin{array}{c}\text { Source } 1 v s \\
\text { Extract of males } v s\end{array}$} & \multirow{3}{*}{$\begin{array}{l}\text { Source } 2 \\
\text { solvent }\end{array}$} & \multirow{2}{*}{$\begin{array}{l}\text { Sex responding } \\
\text { Male }\end{array}$} & \multicolumn{2}{|c|}{$\begin{array}{c}\text { Response }^{\mathrm{b}}(\%) \text { to } \\
\text { source } 1 \text { vs. } \text { source } 2\end{array}$} \\
\hline & & & & $5 \mathrm{a}$ & $10 \mathrm{a}$ \\
\hline & & & Female & $10 \mathrm{a}$ & $10 \mathrm{a}$ \\
\hline \multirow[t]{2}{*}{2} & \multirow[t]{2}{*}{ Extract of females $v s$} & \multirow[t]{2}{*}{ solvent } & Male & $15 \mathrm{a}$ & $30 \mathrm{a}$ \\
\hline & & & Female & $20 \mathrm{a}$ & $10 \mathrm{a}$ \\
\hline \multirow[t]{2}{*}{3} & \multirow[t]{2}{*}{ Extract of males + host plant $v s$} & \multirow[t]{2}{*}{ solvent } & Male & $60 \mathrm{a}$ & $5 b$ \\
\hline & & & Female & $50 \mathrm{a}$ & $10 \mathrm{~b}$ \\
\hline \multirow[t]{2}{*}{4} & \multirow{2}{*}{ Extract of females + host plant $v s$} & \multirow[t]{2}{*}{ solvent } & Male & $15 \mathrm{a}$ & $25 \mathrm{a}$ \\
\hline & & & Female & $15 \mathrm{a}$ & $10 \mathrm{a}$ \\
\hline \multirow[t]{2}{*}{5} & \multirow{2}{*}{\multicolumn{2}{|c|}{ host plant $v s$ air }} & Male & $25 \mathrm{a}$ & $5 b$ \\
\hline & & & Female & $25 \mathrm{a}$ & $5 b$ \\
\hline \multirow[t]{2}{*}{6} & \multirow[t]{2}{*}{ Extract of males + host plant $v s$} & \multirow[t]{2}{*}{ host plant + solvent } & Male & $50 \mathrm{a}$ & $15 b$ \\
\hline & & & Female & $40 \mathrm{a}$ & $15 b$ \\
\hline
\end{tabular}

${ }^{\mathrm{a}}$ See experimental part for details. ${ }^{\mathrm{b}}$ Numbers followed by the same letter are not significantly different $(t$ test; P $\leq 0.05)$.

Our bioassays clearly show that both sexes of the papaya borer weevil are attracted to mixtures of volatiles of males and their host plant, indicating the presence of a male-produced aggregation pheromone that acts in synergism with host plant kairomones.

The gas chromatograms of volatiles from males and females of P. obesus show three male-specific components, represented by compounds a (main $77 \%$ ), $\mathbf{b}$ (intermediate $14 \%$ ), and $\mathbf{c}$ (minor $9 \%$ ), providing a chemical support for the data from bioassay 3 and 6 (Figure 1).

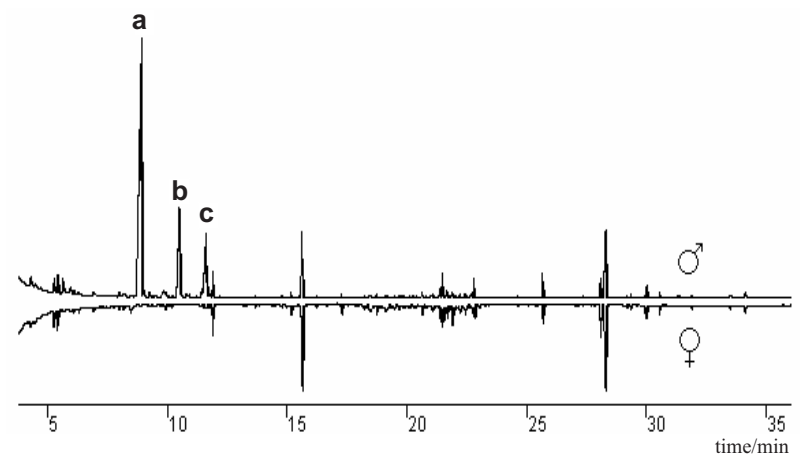

Figure 1. GC analysis of volatiles obtained from male and female $P$. obesus insects, showing three male-specific compounds, $\mathbf{a}, \mathbf{b}$ and $\mathbf{c}$.

Investigations by coupled gas chromatography-mass spectrometry provided analytical data and fragmentation pattern that strongly suggested $\mathbf{a}$ and $\mathbf{b}$ to be grandisal [KI 1127/DB-5; ions of $m / z$ 67, 68 (base peak), 108, and $152 \mathrm{M}^{+}$] and grandisol [KI 1212/ DB-5; ions of $\mathrm{m} / \mathrm{z}, 67,68$ (base peak), 109, and $154 \mathrm{M}^{+}$], respectively (Figure 2). ${ }^{13,14}$ Structural assignments were confirmed upon co-injection with authentic samples. The structure of the minor compound $\mathbf{c}$ remained unidentified. However, the GC-MS analysis [KI 1271/ DB-5; ions of $m / z$ 69, 111, 139 (base peak), and $152 \mathrm{M}-18$ ] (not shown) suggest the structure as a new grandisol derivative.
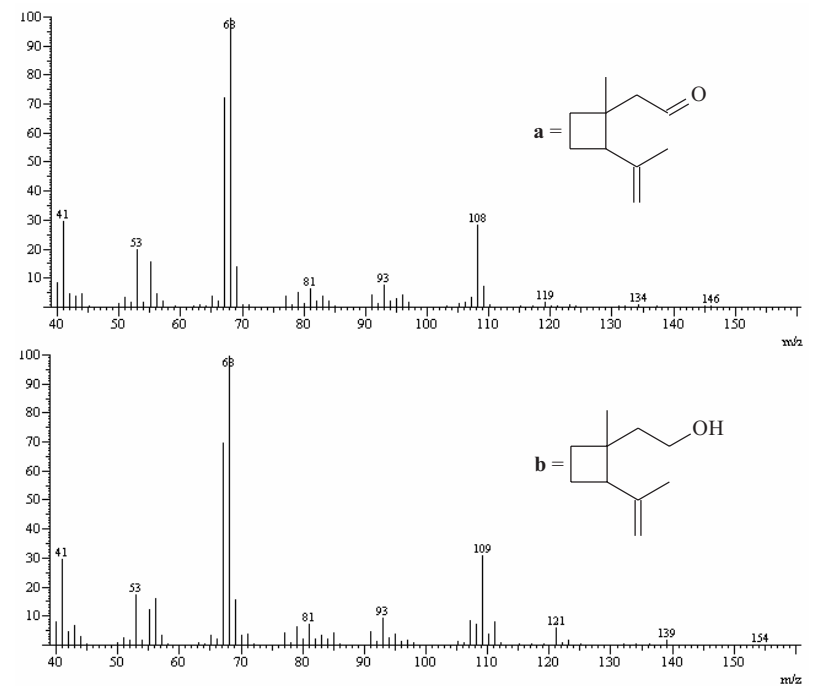

Figure 2. MS and chemical structures of compounds a, grandisal, and $\mathbf{b}$, grandisol.

To determine the absolute configuration of grandisal a and grandisol $\mathbf{b}$, enantioselective gas chromatography was used, employing a modified cyclodextrin as the stationary phase. While the enantiomers of grandisol could not be separated, the corresponding trifluoroacetates showed base line separation under the used conditions, providing an $\alpha$-value of 1.026 (rt (-)-grandisol: rt (+)grandisol) (Figure 3). Comparison of the retention time of the derivative of the natural grandisol with those of synthetic samples, revealed the natural product to be the enantiomerically pure $(1 R, 2 S)$-isomer. Grandisal could not be resolved under the employed condition, however, treatment of the crude extract with lithium aluminium hydride, followed by trifluoroacetylation ${ }^{10}$ exclusively produced the trifluoroacetate of $(1 R, 2 S)$-grandisol while the mixture did no longer contain grandisal. Therefore, the grandisal produced by male $P$. obesus shows $(1 R, 2 S)$ configuration (Figure 4). 


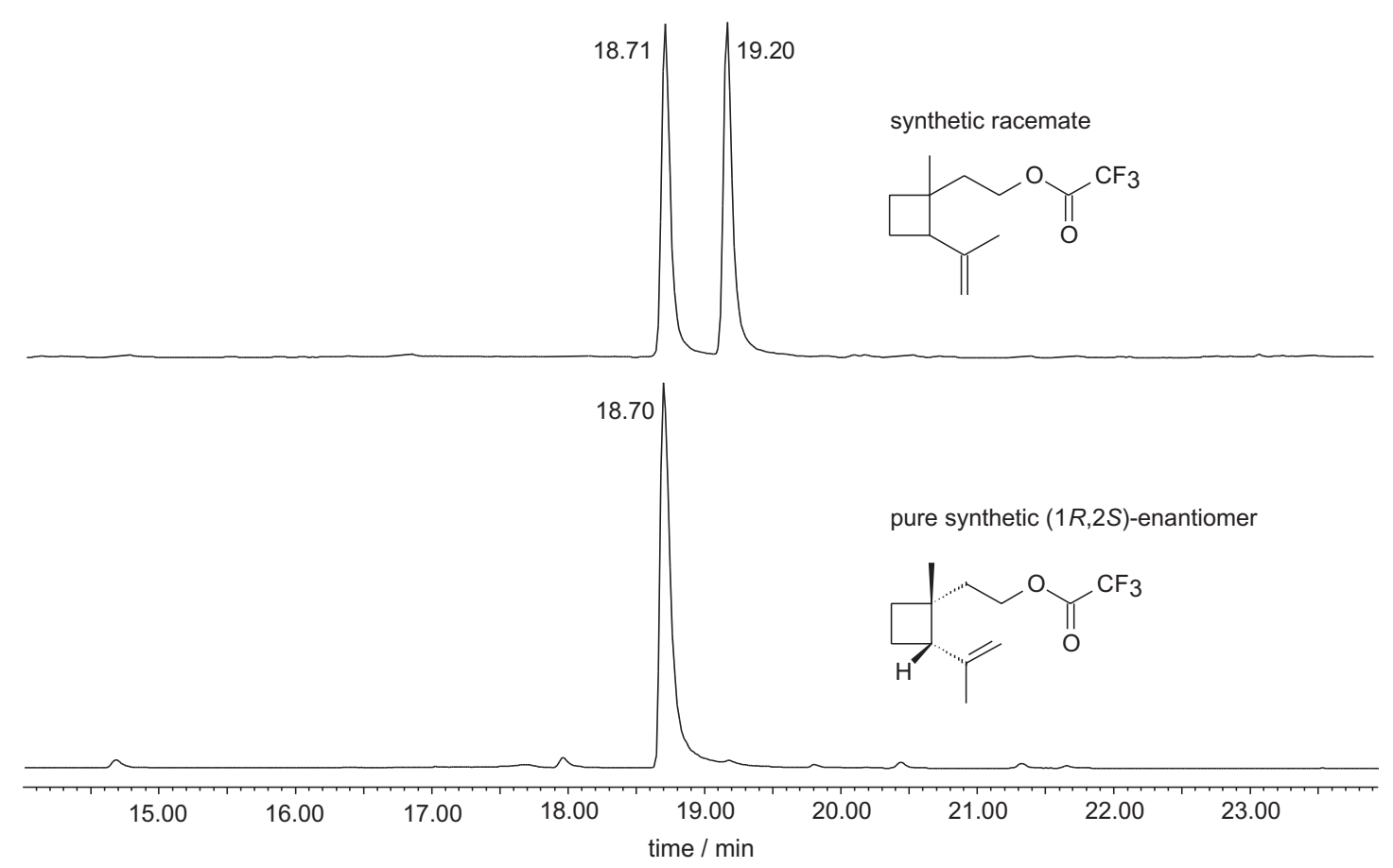

Figure 3. GC of racemic trifluoroacetylated grandisol and $(1 R, 2 S)-(+)$-grandisol trifluoroacetylated.

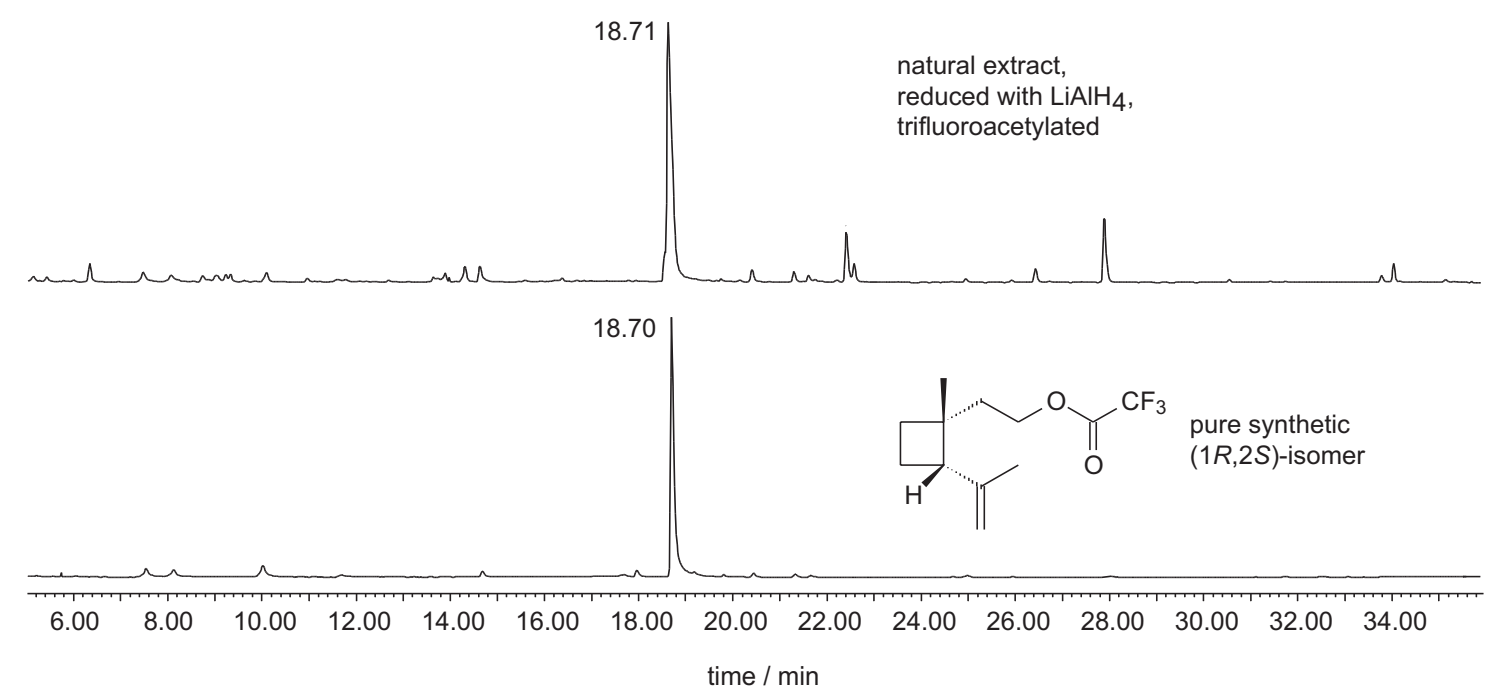

Figure 4. GC of reduced trifluoroacetylated natural extract and trifluoroacetylated $(1 R, 2 S)-(+)$-grandisol.

Both grandisal and grandisol are widespread components of weevil pheromones. ${ }^{15}$ Grandisol produced by $P$. obesus shows the same $(1 R, 2 S)$-configuration as in Anthonomus and Pissodes species. ${ }^{15}$ The configuration of grandisal produced by the papaya weevil is again the pure $(1 R, 2 S)$-enantiomer. In contrast, that of the pine weevil Pissodes strobi shows an enantiomeric excess of only $20 \%$, while that of Pissodes nemorensis is even represented by the almost pure $(1 S, 2 R)$-enantiomer. ${ }^{10}$ The enantioselective biosynthesis of grandisol and grandisal appear to be significant for the behavior and interspecific discrimination of certain species of weevils. ${ }^{16}$ Pheromone biosynthesis has been investigated in several representative species from families of Coleoptera, as in the Scarabaeidae, ${ }^{17}$ however, the studies of pheromone production by the weevils have focused on the boll weevil, Anthonomus grandis. ${ }^{18}$

Synergistic actions between pheromones and host plant odors are widespread among insects, and have been reported for more than 34 weevil species. ${ }^{15,19-22}$ The attractivity of aggregation pheromones that contain both grandisal and grandisol as in Pissodes species, like $P$. nemorensi ${ }^{23}$ and $P$. approximatus,${ }^{24}$ is strongly augmented by host volatiles. 
Our results demonstrate that communication in $P$. obesus is mediated by semiochemicals, more specifically by insect produced aggregation pheromones in combination with plant produced kairomones. The male specific $(1 R, 2 S)$-grandisal $\mathbf{a},(1 R, 2 S)$-grandisol $\mathbf{b}$ and the yet unknown minor component $\mathbf{c}$ are the most important pheromone candidates in the species. Studies are underway to elucidate the structure of the unknown compound, in order to be possible to evaluate the biological activity of the complete 3-component blend on P. obesus. Similarly, investigations on the identification of the structures of plant volatiles that act as synergists are in progress.

\section{Acknowledgments}

We thank the International Foundation for Science Sweden, Organization for the Prohibition of Chemicals Weapons - Netherlands, CNPq and Embrapa/Prodetab, as well as, the Fonds der chemischen Industrie, Germany, for financial support.

\section{References}

1. Moreira, M. A. B.; Zarbin, P. H. G.; Rosado-Neto, G. H.; Barreto, M F. P.; Sobrinho, J. F. da; Borges, M.; Circular Técnica, Embrapa Tabuleiros Costeiros 2003, 35.

2. Giblin-Davis, R. M.; Oehlschlager, A. C.; Perez, A.; Gries, G.; Gries, R.; Weissling, T. J.; Chinchilla, C. M.; Peña, J. E.; Hallet, R. H.; Pierce, H. D., Jr.; Gonzalez, L. M.; Fla. Entomol. 1996, 79, 153.

3. Sousa, W. O.; Rosado-Neto, G. H.; Moreira, M. A. B.; Zarbin, P. H. G.; Rev. Bras. Entomol. 2004, 48, 331.

4. Zarbin, P. H. G.; Ferreira, J. T. B.; Leal, W. S.; Quim. Nova 1999, 22, 263.

5. Zarbin, P. H. G.; Arrigoni, E. D. B.; Reckziegel, A.; Moreira, J.A.; Baraldi, P.T.; Vieira, P.C.; J. Chem. Ecol. 2003, 29, 377.

6. Moreira, M. A. B.; Zarbin, P. H. G.; Abstracts of the $26^{a}$ Reunião Annual sobre Evolução, Sistemática e Ecologia Micromoleculares, Niterói, Brazil, 2004.
7. Baker, T. C.; Lin, C. E. In Techniques in Pheromone Research; Hummel, H. E.; Miller, T.H., eds; Springer-Verlag: New York, 1984.

8. Mori, K.; Fukamatsu, K.; Liebigs Ann. Chem. 1992, 489.

9. Zarbin, P. H. G.; Borges, M.; Santos, A. A.; Oliveira, A. R. M.; Simonelli, F.; Marques, F. A.; J. Braz. Chem. Soc. 2000, 11, 424.

10. Hibbard, B. E.; Webster, F. X.; J. Chem. Ecol. 1993, 19, 2129.

11. Attygale, A. B. In Methods in Chemical Ecology V1; Millar, J. G.; Haynes, K. F., eds.; Kluwer Academic Publishers: Norwell, 1998, ch. 7.

12. Statistica, Stat soft, Inc.; Statistic For Windows, UK, 1999.

13. Tumlinson, J. H.; Gueldner, R. C.; Hardee, D. D.; Thompson, A. C.; Hedin, P. A.; Minyard, J. P.; J. Org. Chem. 1971, 36, 2616.

14. Hedin, P. A.; J. Chem. Ecol. 1977, 3, 279.

15. Bartelt, R. J. In Pheromones of non-Lepidopteran Insects Associated with Agricultural Plants; Hardie, J.; Minks, A. K., eds.; CAB International: London, 1999.

16. Dickens, J.C.; Mori, K.; J. Chem. Ecol. 1989, 15, 517.

17. Leal, W.S.; Zarbin, P.H.G.; Wojtasek, H.; Ferreira, J.T.; Eur. J. Biochem. 1999, 259, 175.

18. Hedin, P.A.; Lindig, O.H.; Wiygul, G.; Experientia 1982, 38, 375.

19. Plarre, R.; Vanderwel, D. C. In Pheromones of nonLepidopteran Insects Associated with Agricultural Plants; Hardie, J.; Minks, A. K., eds.; CAB International: London, 1999.

20. Landolt, P. J.; Phillps, T. W.; Annu. Rev. Entomol. 1997, 42, 371.

21. Weissling, T. J.; Giblin-Davis, R. M.; Scheffraha, R. H.; J. Chem. Ecol. 1993, 19, 1195.

22. Budenberg, W. J.; Ndiege, I. O.; Karago, F. W.; J. Chem. Ecol. 1993, 19, 1905.

23. Phillips, T. W.; West, J. R.; Foltz, J. L.; Silverstein, R. M.; Larnier, G. M.; J. Chem. Ecol. 1984, 10, 1417.

24. Booth, D. C.; Phillips, T. W.; Claesson, A.; Silverstein, R. M.; Lanier, G. N.; West, J. R.; J. Chem. Ecol. 1983, 9, 1.

Received: November 8, 2006 Web Release Date: August 20, 2007 